\section{ECONOMICS}

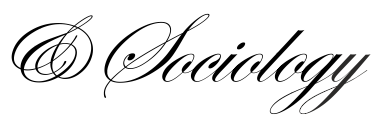

Davidovitch, N., \& Eckhaus, E. (2020). The attitude of academic faculty to continued work by faculty members after reaching retirement age. Economics and Sociology, 13(2), 123-135. doi:10.14254/2071-789X.2020/13-2/9

\title{
THE ATTITUDE OF ACADEMIC FACULTY TO CONTINUED WORK BY FACULTY MEMBERS AFTER REACHING RETIREMENT AGE
}

\author{
Nitza Davidovitch \\ Ariel University, Israel \\ E-mail:d.nitza@ariel.ac.il \\ Eyal Eckhaus \\ Ariel University, Israel \\ E-mail: eyale@,ariel.ac.il \\ ORCID 0000-0002-1815-0045
}

Received: September, 2019

1st Revision: April, 2020

Accepted: June, 2020

DOI: $10.14254 / 2071-$

789X.2020/13-2/9

JEL Classification: E24, J21
ABSTRACT. This study is a pioneer study that examines directly how lecturers and other faculty members perceive the possibility of continued faculty work in research and teaching after reaching the retirement age. The topic of retirement age and the possibility of continuing to work beyond this age is a well-known issue that is arousing interest in general and in academia in particular. This is true especially in non-physical activities. Hence, the question is what is the added value and what are the limitations of retirement age in academia? 108 questionnaires administered to senior faculty were collected in a case study of a single university. Qualitative and statistical research tools were used, with the aim of creating a model that expresses faculty members' perception of work after reaching retirement age. The research findings indicate that even lecturers who are in favor of the retirement age restriction understand the value of emeriti experience and support their continued academic activity in research, guidance and, partially, in teaching. The condition is that the continued academic activity of emeriti shall not block the employment of young faculty members at academic institutions.

Keywords: retirement age, employment, work capability, faculty members

\section{Introduction}

When reaching retirement age, one is entitled to stop working for the reasons of age and to receive a retirement pension and other social rights. This age is determined by law and in agreements between the government and the workers through worker committees (Achdut \& Litwin, 2008). In the Western world, retirement age was determined over 130 years ago by German Chancellor Otto von Bismarck, who in the late $19^{\text {th }}$ century decided that beginning from age 65 it would be possible to retire and to receive an old-age pension. At that time, the average life expectancy was less than 60 , which was why Bismarck allowed himself to make the Germans such a generous offer (Achdut \& Gera, 2008). 
Accordingly, in many countries including Israel, for many years the retirement age was 60 for women and 65 for men.

In time and following the rising life expectancy, several processes occurred in some countries (Hantman, 2012): On April 1, 2004, the Retirement Age Law was enacted in Israel, defining three concepts (Klinov, 2007); Retirement: The age when a person is entitled to retire from work due to age and to receive, depending on the terms determined by law or by agreement, a pension due to the retirement. This age is 67 for men. For women, until the end of February 2018 it was 62 and it is slated to rise gradually, reaching 64 in July 2023. Early retirement age: The age when a person is entitled to receive a pension, if the suitable conditions are met, when retiring due to age even before reaching retirement age. This age is 60 for men and women. Mandatory retirement age: The age when it is possible to compel a worker to retire due to age. This age is 67 for men and women. The Supreme Court has ruled that this instruction is discriminatory on the basis of age but valid.

In addition, with regard to retirement age there is a distinction between those engaged in different occupations. For example, a different retirement age than the legal age (lower or higher) was determined for judges, through legislation and collective agreements. The National Labor Court ruled that an employer must consider a worker's request to continue working after retirement age on a practical basis (Klinov, 2007).

Many articles have been written on this topic of retirement, based on the studies in Israel and elsewhere, from various perspectives:

- From a financial perspective - with regard to security and savings, as well as participation of older population at the labor market (Klinov, 2001) - state of affairs and significance for policy, and trends concerning patterns of employment and preparation of retirees (Kimhi \& Shraberman, 2013).

- From a social perspective (Achdut \& Gera, 2007; Hantman, 2012), with regard to security and lack of social security at retirement age.

- From a statistical perspective (Paltiel, Spolker, Konilko \& Maldondo, 2011; Brodsky, Schneor \& Be'er, 2015), revealing data on the state of retirees and forecasts for the future.

- From the perspective of the healthcare system (Bank \& Casanova, 2003).

- From a gender perspective (Pleau, 2010). The retirement age for women is lower than for men, although their life expectancy is higher (Achdut, Tur-Sinai \& Troitsky).

- And from an educational perspective - with regard to guidance concerning leisure (Leitner \& Leitner, 2014).

The current study is a pioneer study that explores directly how lecturers and faculty perceive the possibility of continued research and teaching by faculty after reaching the retirement age.

The topic of retirement age and the option of working beyond this age is a well known issue that is arousing interest in general and in academia in particular. The latter involves work that is not physical and encompasses research, teaching, guidance, as well as participation in academic committees and conferences. Hence, the question is what is the added value and what are the limitations of retirement age restrictions in academia?

\subsection{About working - retirement - working}

One modern development evident in OECD data, among others, is that in all fields of employment there are often workers who retire but continue working. This is true of the private sector - and is also customary at present in the public sector, through unique agreements with 
workers for whom there is a demand by the system (Brodsky, Schneor \& Be'er, 2015). In Israel, people from age 67-70 can work and their contract at the university is renewed annually. They are not employed elsewhere as well, rather only at the university. These are usually people with administrative jobs.

Where in 2011 those with part time jobs constituted some $19 \%$ of all workers, a decade later the number has dropped to $15.5 \%$. OECD data indicate an opposite trend - from $17 \%$ the number has risen to about $18 \%$. Another significant datum is unemployment levels, which were $6.3 \%$ among those aged 56-64 in 2001, rose to $7.3 \%$ in 2005, and in 2011 dropped to only $4.2 \%$ - again an opposite trend to the OECD (Brodsky, Schneor \& Be'er, 2015).

Older persons continue to work for the same reasons as all ages, which include a desire for self-fulfilment, being an active participant in the economy and public life and to enjoy the benefits that work brings (Byrnes, Doron, Georgantzi, Mitchell \& Sleap, 2019).

Many governments are reforming pension schemes due to ageing of the population (Vermeer, Mastrogiacomo \& Van Soest, 2016). Early retirement provisions account for a large proportion of the drop in the labor force participation of elderly workers (Conde-Ruiz \& Galasso, 2003). Decisions in countries vary. In Norway, early retirement programmes reduced the retirement age from 67 to 62 for a majority of the labour force (Hernoes, Sollie \& Strøm, 2000), while pension reforms in Austria which increased the early retirement age from 60 to 62 for men and from 55 to 58.25 for women (Staubli \& Zweimüller, 2013). This increase resulted in increased employment by 9.75 percentage points among affected men and by 11 percentage points among affected women (ibid).

Efforts are being made to submit a private bill that will cancel mandatory requirement in Israel, as in the US, Australia, Canada, and the UK (in these countries academics over 70 continue to work with zeal). The meaning of such a law is that people will still be eligibile for retirement pensions, but those who wish to continue working will be able to do so and will not be compelled to retire (Tur-Sinai, 2016).

\subsection{About retirement and gender}

For years the hot potato called "raising the retirement age for women" has been under discussion, but the Israeli government has not managed to reach a courageous decision on this sensitive matter (Tur-Sinai, 2016, Avisar, 2019).

As stated, in Israel there is a discrepancy between the retirement age of men, which is 67 , and that of women who retire at age 62. This historical discrepancy remains despite the lack of any economic logic. The life expectancy of women is higher than that of men. Moreover, their average pay is lower than that of men, such that they put aside less for retirement. Furthermore, women work less than men on average, among other things due to maternity leave that interrupts their employment continuity.

When comparing Israel to that customary in OECD countries, it is evident that of 35 countries only in 6 is there a disparity in retirement age between men and women, where in Israel the disparity between men and women is the highest (aside from Austria, where there too men's retirement age is 5 years higher than that of women).

The data show that, in contrast to the OECD average, the retirement age for men in Israel is higher, 67 versus 64.6. Nonetheless, among women in Israel the opposite is true - the official retirement age of Israeli women is 62, versus an average of 63.9 in OECD countries.

If the data are so clear, why is the government still finding it difficult to push a decision to raise the retirement age for women? The reason is the situation in Israel's labor market, which in many cases sees the employment of older people as a burden. 


\subsection{Is there a connection between retirement and changes in life expectancy?}

As stated, some 130 years have gone by since the "retirement age" was determined. Life expectancy has jumped to about 80 and the rise is consistent, with retirement age in the western world remaining almost unchanged. Bank of Israel data show that while in 2016 the proportion of those aged 65 and older was $11 \%$ of the public, by 2045 they are expected to comprise $15 \%$ of the population, i.e., an increase of $36 \%$. According to another forecast the number of senior citizens in Israel, at present nearly 900 thousand, will reach 1.7 million in 15 years (Tur-Sinai, 2016; Avisar, 2019) (Table 1).

Table 1. Retirement age in OECD countries

\begin{tabular}{lccl}
\hline Country & Men & Women & Expected change \\
\hline Israel & 67 & 62 & $\begin{array}{l}\text { The decision to raise the retirement } \\
\text { age to } 64 \text { was stalled }\end{array}$ \\
\hline OECD average & 64.6 & 63.9 & \\
\hline US & 66 & 66 & Will be raised to 67 by 2027 \\
\hline Italy & 66.7 & 66.7 & Will be raised to 67 by 2027 \\
\hline Germany & 65 & 65 & Will be raised to 67 by 2027 \\
\hline Japan & 65 & 65 & \\
\hline Spain & 65 & 65 & Will be raised to 67 by 2027 \\
\hline Sweden & 65 & 65 & \\
\hline UK & 65 & 64 & \\
\hline Denmark & 65 & 65 & Will be raised to 67 by 2030 \\
\hline Canada & 65 & 65 & \\
\hline
\end{tabular}

Notably, the aging of the population is a process that is prevalent the world over, and Israel's status compared to developed countries is relatively good due to the high birth rate.

\subsection{Adaptation of the employment market}

Some refer to the necessary distinction between professional fields: in white collar professions, such as lawyers and doctors, there is almost no problem. On the contrary, older age is usually a sign of seniority, and many of these professionals are already working beyond the official retirement age.

The problem is more conspicuous in blue collar professions and in strenuous or physical jobs. The combination of raising the retirement age with few options for employment of older people in this field might lead to severe effects among weak populations.

There are various ways of changing the employment market to make it more suitable for older people. For instance, providing tax incentives and grants to employers who employ older people or investing in career change training for adults. It is also necessary, of course, to perform additional adjustments such as in work hours (Weissberg, 2012).

For example, many elementary school teachers are older people who switched to teaching. In this way, older populations find employment and the schools receive experienced high quality workers.

Around the world as well, older people are undergoing retraining for jobs in the police that involve supervision more than use of physical force (Atzmon, 2017). There is a long list of professions that are suitable for older populations and some say that the government should help by encouraging the employment of older people.

In summary, the question is whether older and vibrant people who acquired skills over many decades should be sent home due to their age, similar to a product that has reached its 
due date (Weissberg, 2012). The court determined that if a worker asks to continue working after the age of 67, the employer must consider this on a practical and individual basis (Atzmon, 2017).

\subsection{Not everywhere are people compelled to retire}

Age discrimination is termed "ageism" and in recent years legal awareness of it has been growing, particularly with the rise in life expectancy. The original retirement age, 65, was set according to the retirement age instituted in Germany in 1889, when life expectancy was 49 years. Nonetheless, the retirement age has not been updated since then, and even by law it was raised by only two years, to 67. In most European countries, the retirement age is 65 and is identical for men and women. This is true of Germany, the Netherlands, and Sweden as well. In France the age is 60, while in Denmark it is 67 (Avisar, 2019).

In the US the mandatory retirement age was cancelled in 1986, aside from exceptional cases defined by law. However according to Steve Adler, retired president of the National Labor Court, "One possible explanation that no chronological retirement age has been set in the US is that workers can be fired at will, so long as the termination is justified. However, in Israel it is harder to terminate workers". In the UK, a law was enacted in 2011 whereby age 65 is no longer considered suitable for retirement. This means that an employer who sets a mandatory retirement age must justify both setting mandatory retirement and the specific age chosen. Other countries where the obligation to retire at a certain age was cancelled are Australia, New Zealand, Greece, and Finland (Tur-Sinai, 2016).

A study published by the Bank of Israel supports raising the retirement age (Cohen, 2019). The study examined the effects of raising the retirement age beginning from 2004 and found that raising the legal retirement age has led to a significant rise in the actual retirement age. The study also shows that raising the retirement age for women might contribute to increasing their financial well-being when retiring (Tur-Sinai, 2016).

The study, conducted by the research division of the Bank of Israel, examined the effective retirement age of men and women in different population groups using three indices. The need for different indices arose from the lack of official data on the effective retirement age.

\subsection{Rationale for the study}

In the current study we explored the attitude of academic faculty to the continued work of faculty members after reaching retirement age. The work of faculty in academic institutions is characterized (Milgram \& Davidovitch, 2010) by a wide range of activities that include: teaching, research, research publications, presentations at conferences, submitting research grants, academic administration, community service, and others. Their work encompasses the ability to generate the next generation of researchers and to produce new knowledge that meets international standards. There is flexibility with regard to the decision when to work, with whom, and how much.

Accordingly, in this field the question of the relevance of "retirement" seems artificial, unnatural, and inappropriate.

In the last decade, academic faculty members have objected to the Retirement Age Law in Israeli academia. In addition, a bill revoking the obligation to retire - as in the US, the UK, and Canada - has been initiated. This, although according to government service regulations workers cannot remain at their workplace after age 70, aside from exceptional cases (Avisar, 
2019). In practice, efforts to cancel age-mandated retirement are focused on canceling the current legal right to compel workers to retire at the age of 67.

The claim is that the obligation to retire contradicts the Law of Equal Employment Opportunity.

Israel prize laureate, law professor Ruth Ben-Israel, was among those who appealed to the Supreme Court to cancel the retirement age obligation. The appellants claim that the section requiring retirement at a certain age is unconstitutional and discriminatory (Gorali, 2014).

"I wish to present to the court my personal experience when retiring from my job at Tel Aviv University in 2000, a traumatic event for me whose consequences and meanings I am experiencing to this day. Nothing in my past prepared me for the intensity of the bad experience and humiliation to which I was exposed."

Thus writes Prof. Ruth Ben Israel in her statement to the Supreme Court as part of the appeal seeking to cancel the mandated retirement age, now set at 67 . Ben Israel sought to join the appeal submitted by Professors Asa Kasher, Mordechai Segev, and Moshe Gavish. Their appeal sought to cancel section 4 of the Retirement Age Law on the grounds of being unconstitutional and discriminatory on the basis of age.

In addition, the National Labor Court ruled that retiring when reaching retirement age is not automatic, but did not reach a decision on whether the section in the Retirement Age Law is legal and left this to the Supreme Court.

Ben Israel was forced to retire in 2000, but the Law Faculty at Tel Aviv University continued to employ her nonetheless. "Until reaching retirement my office was on the fourth floor with all the active faculty, facilitating daily collaborations.

"After my employment was terminated I cleared out my office and was transferred to the basement floor, far from the academic discourse", she writes and complains that in the faculty's newsletter her name was listed with those who had retired and her title was changed from Full Professor to Professor Emeritus. "These may seem like external signs, but the meaning is that I am already excluded from the faculty".

Ben Israel also notes the effect on her salary and on the partial pension to which she is entitled, among other things because she transferred from the Hebrew University to Tel Aviv University.

"The continued employment made me eligible for a lower salary that lacked the essential salary components. This was humiliating. The reduced salary contradicted the Law of Equal Employment Opportunity, as it resulted from my reaching retirement age and was thus age-related discrimination, and contradicted the legal obligation to pay an equal salary for equal work. I explained to my students that I had lost even the right to demand my rights by law, as the moment I demanded an equal salary my employment contract would not be renewed".

She concludes: "The mandatory retirement that excluded me from my work humiliated me, trampled my right to support myself with human dignity, and harmed my right to support myself with financial dignity".

In his declaration, Prof. Segev confronted the Technion's argument that retirement age does not compel one to "leave the productive system of society in general and of academia in particular."

He claims that transferring Full Professors to the status of Professors Emeritus is "the beginning of a steep incline that involves reducing their rights and fields of activity, until in a short time the large majority are removed from any academic and productive activity" by reducing budgets, research grants, assistance in the labs, student guidance, and others.

The claim is that the state cannot have it both ways - raise the retirement age and claim that older people are occupying jobs that could have employed the young. The academics 
claimed that they are at the height of their abilities, have accumulated a great deal of experience, and do not want this to be wasted.

In light of the research literature, the current research hypotheses are that:

H1. Those who support a retirement age for academic faculty, are in favor of the participation of faculty members in other academic activities, aside from teaching and research, when reaching retirement age.

H2. Those who support a retirement age for academic faculty in order to enable the entrance of new faculty members, are in favor of the participation of faculty members in other academic activities, aside from teaching and research, when reaching retirement age.

H3. Those who support a retirement age for academic faculty in order to accept new faculty members, are also in favor of the participation of faculty members in partial teaching positions, when reaching retirement age.

H4. Those who support retirement age for academic faculty in order to accept new faculty, are also in favor of the participation of faculty members in student guidance, when reaching retirement age.

H5. Those who support retirement age for academic faculty in order to accept new faculty members, are also in favor of the participation of faculty members in research, when reaching retirement age.

\section{Methodological approach}

\subsection{Measurement Tool}

A questionnaire was used for data collection, with three open-ended questions:

1. Do you think the work of a faculty member should be limited to retirement age?

2. Do you think there is an advantage in using the retirement age limit to enable the entrance of new faculty members?

3. What are the steps you think you should take to enable employment of retirement age staff?

\subsection{Initial Sample}

The questionnaires were distributed online to the senior faculty members of Ariel University, Israel, who have full time position, using Google Docs, during June 2019 - July 2019 One hundred and eight completed questionnaires were collected, out of 220 distributed. Of all respondents, $47.6 \%$ were female and $52.4 \%$ male. Respondents' age ranged from 36-49 (36.6\%), 50-60 (32.3\%), and 61-84 (31.2\%).

\subsection{Analysis}

In the first step, we manually read all respondents' replies and identified major themes (Davidovitch \& Eckhaus, 2018; Eckhaus \& Davidovitch, 2018a, 2018b). This process is known as manual text categorization (Narhari \& Shedge, 2017). Based on these categories the model was constructed. Table 2 lists the categories. 
Table 2. Main themes

\begin{tabular}{ll}
\hline \multicolumn{1}{c}{ Variable } & \multicolumn{1}{c}{ Theme } \\
\hline Txt1_yes & Responded positively to question 1 \\
\hline Txt2_yes & Responded positively to question 2 \\
\hline Partly & Partial employment \\
\hline Guidance & Guiding students and young researchers \\
\hline Other & $\begin{array}{l}\text { Other activities than official teaching and research, such as volunteering in } \\
\text { the institution, helping students with difficulties, etc. }\end{array}$ \\
\hline Research & Performing research \\
\hline
\end{tabular}

Categories were binary coded(Eckhaus \& Sheaffer, 2018b), i.e., responses were tagged as 0 when they did not belong to the category, and 1 when they did. Table 3 lists the proportion who responded to the third question, illustrated in Figure 1.

Table 3. Reponses to the third question

\begin{tabular}{ll}
\hline & $\mathrm{N}(\%)$ \\
\hline Guidance & $28(25.9 \%)$ \\
\hline Partly & $31(28.7 \%)$ \\
\hline Research & $19(19.4 \%)$ \\
\hline Other & $11(10.2 \%)$ \\
\hline
\end{tabular}

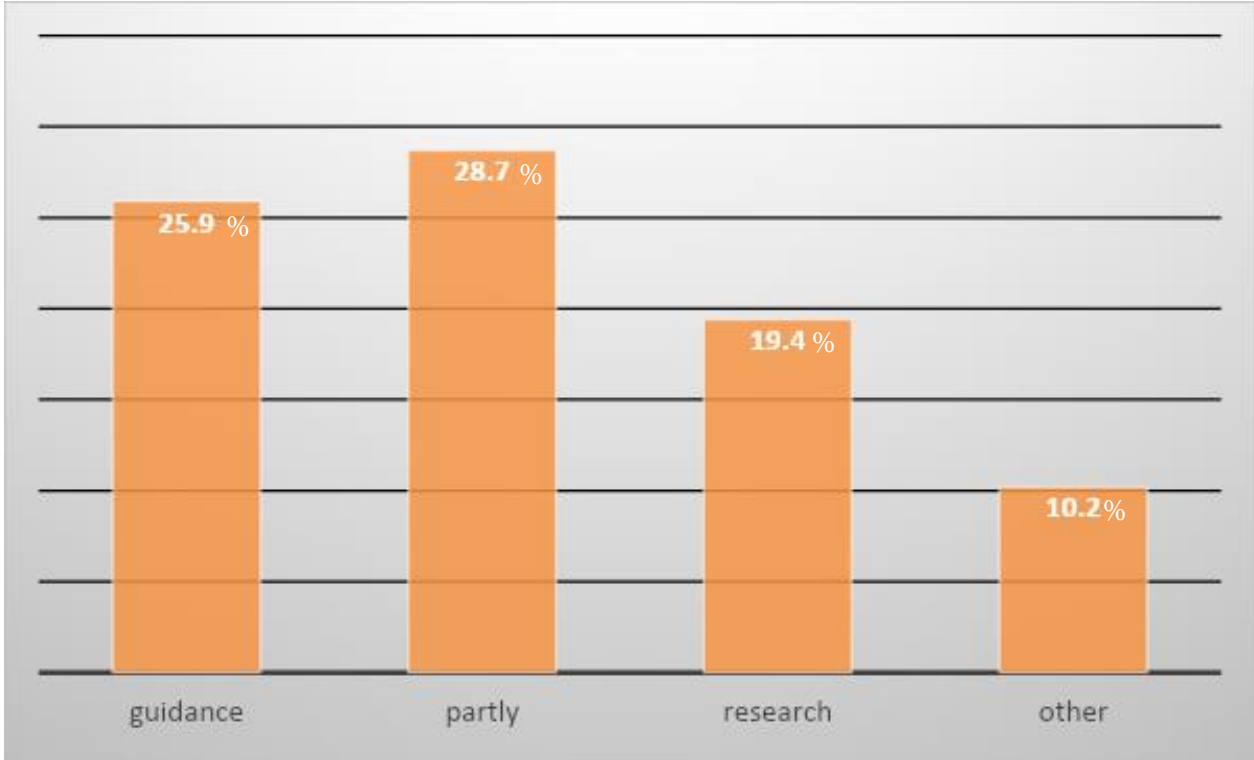

Figure 1. Responses to the third question (in percentages)

We employed a mixed methods research design (Imran \& Yusoff, 2015; Molina-Azorin, 2016), which offers a compliment of strengths of both the qualitative and empirical methods (Eckhaus \& Ben-Hador, 2019; Eckhaus \& Davidovitch, 2019). We used Structural Equation Modeling (SEM) to test the model's goodness-of-fit (Eckhaus, 2019; Eckhaus \& Sheaffer, 2018). Model fit was estimated using CFI, NFI, TLI, RMSEA, and CMIN/DF. Values of CFI, NFI, and TLI $\geq .95$ are indication of a good fit (Hinz et al., 2017), the ratio CMIN / DF should be small (ibid.), a value of $<3$ is typically considered a good fit. RMSEA should be .06 or smaller (Hu \& Bentler, 1999). A correlation between Txt1_yes and Txt2_yes, as they both refer to age employment restrictions. 


\subsection{Examples from respondents}

Here are some examples of people who answered the two questions in the affirmative. This is their response to the third question on the ability of retiring faculty to continue working, in the following areas:

\section{Research and guidance}

- "They should only be employed in research work"

- "They must retire on principle but you can let them, for instance, continue guiding doctoral students if they are experts in their field; give them access to the Scientific Ties Fund; include them in committees and in research. Also, give them an office and a work environment (lab, etc.)

- "Association with research centers, research fellows, workshops, guidance. Less teaching"

- "Guiding research, accompanying young faculty, academic and management consulting for whoever needs it"

- "If they wish to continue contributing to the university and mentoring young students"

\section{Other possibilities}

- "Maybe utilizing their skills and experience in various academic committees. Providing a physical workspace"

- "Other roles at the institution... helping immigrants/learning disabilities, volunteering at the institution"

- "Half a position at the most. Inclusion in initiatives for the benefit of society and of the community."

In summary, faculty members recommend that a unique and flexible track be formed for faculty who reach retirement, such that those interested, at the conclusion of their term, in continuing to participate in academic work, can do so.

\section{Results}

Spearman's correlations, means, and STD are presented in Table 4. Figure 2 illustrates the age retirement contribution model and the results.

Table 4. Correlation matrix: Means and SD

\begin{tabular}{lllllll}
\hline & Txt1_yes & Txt2_yes & Partly & Guidance & Other & Research \\
\hline Txt1_yes & - & & & & & \\
\hline Txt2_yes & $.4^{* * *}$ & - & & & & \\
\hline Partly & -.02 & .17 & - & & & \\
\hline Guidance & .1 & $.21^{*}$ & -.05 & - & & \\
\hline Other & $.29^{* *}$ & .18 & .05 & .14 & - & \\
\hline Research & .01 & $.26^{* *}$ & .05 & .13 & $.20^{*}$ & - \\
\hline Mean & .48 & 1.28 & .57 & .52 & .20 & .37 \\
\hline SD & 2.52 & 6.60 & 3.0 & 2.71 & 1.09 & 1.9 \\
\hline
\end{tabular}

$* p<.05, * * p<.01, * * * p<.001$ 


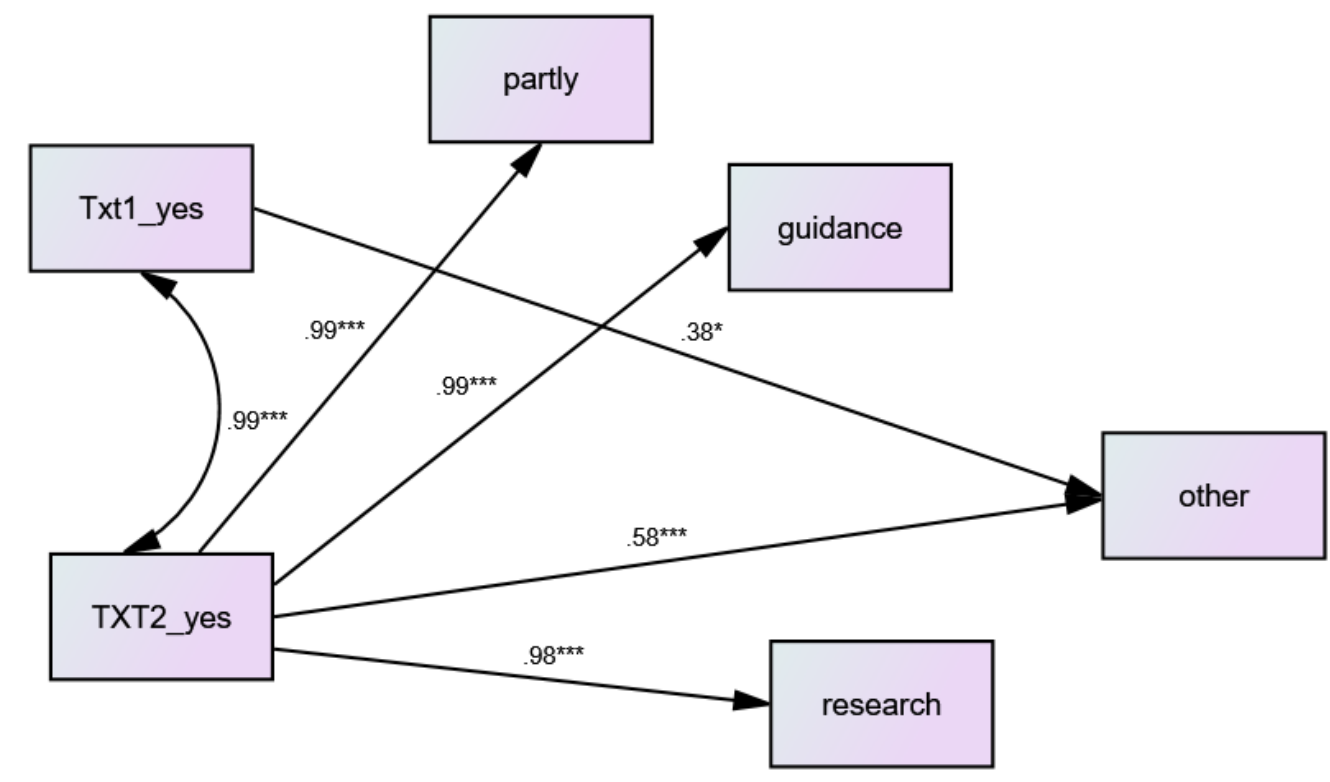

$* * p<.01 . * * * p<.001$.

Figure 2. Age retirement contribution model results

The hypothesized model showed an excellent fit: CMIN/DF $=.28(p>.05), \mathrm{CFI}=1$, $\mathrm{NFI}=1$, TLI=1.01, RMSEA $=0$. All hypotheses were supported. Txt1_yes and Txt2_yes $(\mathrm{H} 1$ and $\mathrm{H} 2$ respectively) positively affect other. Txt2_yes positively affects partly (H3), guidance (H4), and research $(\mathrm{H} 5)$.

Next, we added Age and Gender as controlled variables, i.e., a relationship was added from age and gender to all variables. Model fit measures were not good (TLI<.9, RMSEA>.08, CMIN/DF =8.7) due to several non-significant relationships. However, Age did show a statistically significant relationship with Txt1_yes $(B=-.04, p<.05)$, Txt2_yes $(B=-.03, p<.05)$ and partly $(\mathrm{B}=.05, \mathrm{p}<.01)$. This means that the older the respondents the less they support the employment age restrictions, and the more they support partial teaching.

Gender showed a statistically significant relationship with Txt1_yes $(B=.98, p<.001)$, Txt2_yes $(\mathrm{B}=.99, \mathrm{p}<.001)$ and guidance $(\mathrm{B}=.33, \mathrm{p}<.01)$. This means that males support employment age restrictions and further employment in guiding students, more than do females.

These findings suggest that age and gender indeed impact opinions regarding employment age restrictions, and further research focusing on these variables is needed.

\section{Conclusion}

The current research findings raise the question of policy regarding whether there is room to form a model for working at academic institutions in research and teaching after reaching retirement age.

The researchers estimate that the continued activity of faculty after retirement age, among both men and women, has meaning and impact in the areas of research, teaching, and contribution to the community and as a factor shaping role models for the next generations of researchers.

The research findings indicate that faculty, older as well as younger, support continued academic activity beyond the retirement age. Hence, we expect that in the next few years the retirement age will increase significantly, and in academia - their number will increase even more than in other sectors. 
Faculty who are able and wish to continue working in the academic system can join the academic staff at colleges interested in developing experienced academic faculty, as well as in private colleges. Efforts should be made to bring academic faculty to a situation in which they continue contributing in the fields of research, guidance of students for advanced degrees, and contribution to the community.

The findings show statistical significance with regard to gender and age. These findings show that age and sex indeed affect opinions regarding the limitations of employment age. However adding the variables of gender and age reduced the quality of the model, such that it is not possible to reach unequivocal conclusions and there is need for further research in order to examine these variables and their impact on the attitude to retirement age.

The findings of the current study indicate the significance of prior experience as a valuable variable that must be taken into account when rethinking the limitations of retirement age. The importance of this variable is supported by the literature, which has proven it to be a main key in decision making concerning service providers (Eckhaus, Kogan, \& Pearlman, 2013). Further research on additional implications of prior experience in the academic system might provide further illumination and enhance understanding of this important topic of retirement age.

\section{References}

Achdut, L., \& Gera, R. (2008). Work and retirement among those aged 50 and over in Israel. Bitahon Sotziali, 76, 43-71. [Hebrew]

Achdut, L., \& Litwin, H. (Eds.) (2008). The 50+ cohort - First results from SHARE-Israel: Data from the Survey of Health, Ageing, and Retirement in Israel. Bitzhon Sotziali, 76 March, 43-71. [Hebrew]

Achdut, L., Tur-Sinai, A., \& Troitsky, R. (2015). Transitions among States of Labor Force Participation in the Old Age. European Journal of Ageing, 12(1), 39-49.

Atzmon, E. (2017). Can a worker be required to retire at 67?. June 22, 2017. https://pensuni.com/?p=3984

Avisar, I. (2019). There is no choice: women's retirement age must rise. May 22, 2019. https://www.yediot.co.il/articles/0,7340,L-5513714,00.html

Banks, J., \&Casanova, M; (2003) Work and retirement. In A. Marmot (Ed.),Health, Wealth and Lifestyles of the Older Population in England (pp. 127-166). London: Institute for Fiscal Studies.

Bengtson, V., Giarrusso, R., Mabry, J. B., \& Silverstein, M. (2002). Solidarity, conflict, and ambivalence: Complementary or competing perspectives on intergenerational relationships? Journal of Marriage and Family, 64(3), 568-576.

Brodsky, J., Schneor, Y., \& Be'er, S. (2015). The Elderly in Israel: Statistical Abstract. Jerusalem: JDC, Brookdale Institute, Eshel. [Hebrew]

Byrnes, A. C., Doron, I. I., Georgantzi, N., Mitchell, B., \& Sleap, B. (2019). The right of older persons to work and to access the labour market. Paper submitte to the eleventh session of the United Nations General Assembly Open-ended Working Group of Ageing (6 to 9 April 2020) UNSW Law Research Paper No. 19-101.

Cohen, O. (2019). Recent update: Longer life, more years on the job. March 12, 2019. https://www.davar1.co.il/177970/.

Conde-Ruiz, J. I., \& Galasso, V. (2003). Early retirement. Review of Economic Dynamics, 6(1), 12-36. doi:https://doi.org/10.1016/S1094-2025(02)00018-2

Davidovitch, N., \& Eckhaus, E. (2018). The influence of birth country on selection of conference destination-employing natural language processing. Higher Education Studies, 8(2), 92-96. 
Eckhaus, E. (2019). How to be Happy. Blog section on www.artistila.com. Retrieved from http://www.artistila.com/how-to-by-happy/

Eckhaus, E., \& Ben-Hador, B. (2019). Gossip and gender differences: a content analysis approach. Journal of Gender Studies, 28(1), 97-108. doi:10.1080/09589236.2017.1411789

Eckhaus, E., \& Davidovitch, N. (2018a). Impact of gender and conference size on conference preferences - employing natural language processing. International Journal of Educational Methodology, 4(1), 45-52. doi:10.12973/ijem.4.1.45

Eckhaus, E., \& Davidovitch, N. (2018b). Improving academic conferences - criticism and suggestions utilizing natural language processing. European Journal of Educational Research, 7(3), 445-450.

Eckhaus, E., \& Davidovitch, N. (2019). How do academic faculty members perceive the effect of teaching surveys completed by students on appointment and promotion processes at academic institutions? A case study. International Journal of Higher Education, 8(1), 171-180.

Eckhaus, E., Kogan, K., \& Pearlman, Y. (2013). Enhancing strategic supply decisions by estimating suppliers' marginal costs. Journal of Supply Chain Management, 49(4), 96107.

Eckhaus, E., \& Sheaffer, Z. (2018a). Factors affecting willingness to contribute goods and services on social media. The Social Science Journal. doi:https://doi.org/10.1016/j.soscij.2018.08.001

Eckhaus, E., \& Sheaffer, Z. (2018b). Happiness enrichment and sustainable happiness. Applied Research in Quality of Life. doi:https://doi.org/10.1007/s11482-018-9641-0

Hantman, S. (2012). Social work with the elderly. In N. Hovav, E. Leventhal, \& Y. Katan (Eds.), Social Work in Israel (pp. 462-478). Tel Aviv: Hakibbutz Hameuchad and the Society for the Promotion of Social Work. [Hebrew]

Hernoes, E., Sollie, M., \& Strøm, S. (2000). Early retirement and economic incentives. The Scandinavian Journal of Economics, 102(3), 481-502. doi:10.1111/1467-9442.00211

Hinz, A., Sander, C., Glaesmer, H., Brähler, E., Zenger, M., Hilbert, A., \& Kocalevent, R.-D. (2017). Optimism and pessimism in the general population: Psychometric properties of the Life Orientation Test (LOT-R). International Journal of Clinical and Health Psychology, 17(2), 161-170. doi:https://doi.org/10.1016/j.ijchp.2017.02.003

Hu, L. T., \& Bentler, P. M. (1999). Cutoff criteria for fit indexes in covariance structure analysis: Conventional criteria versus new alternatives. Structural Equation Modeling: AMultidisciplinary Journal, 6(1), 1-55.

Imran, A., \& Yusoff, R. M. (2015). Empirical validation of qualitative data: A mixed method approach. International Journal of Economics and Financial Issues, 5(1S), 389-396.

Kimhi, A. \& Shraberman, K. (2013). Employment and Income Trends Among Older Israelis. State of the Nation Report - Society, Economy, and Policy 2013. Taub Center for Social Policy Studies in Israel, pp. 151-184. [Hebrew]

Klinov, R. (2007). Patterns of Transition into and out of and Unemployment: Israel 1995-2006. Position paper. [Hebrew]

Manning, C.W., \& Romney, L.C. (1973). Faculty Activity Analysis: Procedures Manual. Tech Report No. 44. National Center for Higher Education Management Systems at Western Interstate Commission for Higher Education, Boulder, CL.

Milgram, R. M., \& Davidovitch, N. (2010). Creative thinking and lecturer effectiveness in higher education. The International Journal of Creativity \& Problem Solving, 20(1), 714.

Ministry of Finance (2015). Report of the Supervisor in Charge of the Capital Market, Insurance, and Savings, for 2014. [Hebrew] 
Molina-Azorin, J. F. (2016). Mixed methods research: An opportunity to improve our studies and our research skills. European Journal of Management and Business Economics, 25, 37-38.

Leitner, M.,\& Leitner, S. (Eds.) (2014). Israeli Life and Leisure in the 21st Century. Urbana, IL: Sagamore. ISBN: 978-1-57167-768-6.

Narhari, S. A., \& Shedge, R. (2017). Text categorization of Marathi documents using modified LINGO. Paper presented at the 2017 International Conference on Advances in Computing, Communication and Control (ICAC3).

Paltiel, A., Spolker, M., Konilko, A., \& Maldondo, M. (2011). Long-Term Population Forecasts 2009-2059. Jerusalem: Central Bureau of Statistics. [Hebrew]

Pleau (2010). Gender differences in postretirement employment.Research on Aging, 32, 267303.

Staubli, S., \& Zweimüller, J. (2013). Does raising the early retirement age increase employment of older workers? Journal of Public Economics, 108, 17-32. doi:https://doi.org/10.1016/j.jpubeco.2013.09.003

Tur-Sinai, A. (2016). Employment and retirement among senior citizens in Israel: Main economic features. Jerusalem: Information Center for Research on Aging in the Israeli Population, Hebrew University. [Hebrew]

Gorali, M. (2014). https://www.calcalist.co.il/local/articles/0,7340,L-3623949,00.html

Vermeer, N., Mastrogiacomo, M., \& Van Soest, A. (2016). Demanding occupations and the retirement age. Labour Economics, 43, 159-170. doi:https://doi.org/10.1016/j.labeco.2016.05.020

Weissberg, H. (2012). Academics against the Retirement Age Law: "Leaves the decision to the employer". https://www.themarker.com/career/1.1807705 